\title{
血液透析を施行した高齢急性腎不全患者の実態と看護上の問題点
}

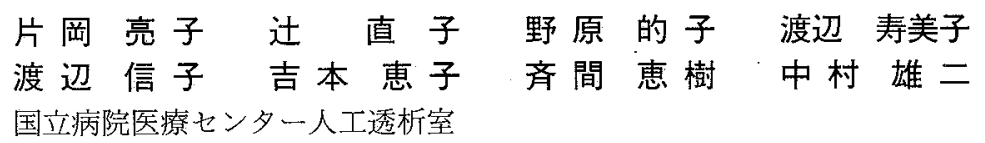

key words: 高齢者, 急性腎不全, 多臟器不全, 予後, 高齢急性腎不全患者の看護, TISS

〈要旨〉

血液透析を施行した高齢の急性腎不全 (ARF) 患者の臨床像, 重症度, 多臓器不全との関係, 予後について検討した。 対象は，1986 年から 1990 年までの 5 年間に当院にて血液透析を施行した 65 歳以上の ARF 患者 46 例 (平均年齢 76.4 歳)とした。ARF の臨床区分としては, 腎性 ARF が $48 \%$ と最も多く, 次いで腎前性 ARF を誘因に腎性 ARF を生じた ものが 37\%, 腎後性 ARF が 15\%であった。腎後性 ARF 以外の ARF の原因および促進因子は, 種々の感染，心不全， 脱水, 薬剤や外科手術であった. 全体の死亡率は $59 \%$ あっただ, ARF より回復した症例も $37 \%$ 認められた. 死亡率

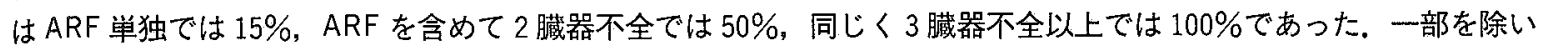
て重症度指数は高く, $90 \%$ の症例はつきっきりの看護を要し, 血液透析法プログラムは一様でなく個々の症例にみあっ た工夫が必要であった。集中管理される患者の身体的・心理的・環境的側面を積極的に配慮すべきであると考えた。

\section{Nursing and clinical problems in hemodialysis for acute renal failure in elderly patients}

Ryoko Kataoka, Naoko Tsuji, Matoko Nohara, Sumiko Watanabe, Nobuko Watanabe, Keiko Yoshimoto, Shigeki Saima, Yuji Nakamura

Dialysis Unit, National Medical Center Hospital

We have analyzed clinical conditions, severity, the relationship with multiple organ failure and prognosis in elderly patients with acute renal failure (ARF) requiring dialysis. This study was conducted on 46 patients over 65 years of age with ARF treated with dialysis in our hospital during the five year period between 1986 and 1990. Regarding the classification of causes leading to ARF, primary renal ARF was most frequent, $48 \%$. Renal ARF secondary to prerenal factors accounted for $37 \%$, and postrenal ARF for $15 \%$. The etiology and precipitating factors of ARF, other than postrenal ARF, were infections, heart failure, dehydration, drugs and surgery. Prognoses are poor in these patients, as described below. The overall mortality rate was $59 \%$. Complete or partial recovery from ARF occurred in $37 \%$ of the patients in this study. The mortality rate increased in ascending order with the numbers of damaged organs; kidney alone (15\%), those with one another organ failure (50\%), and those with more than two other organs $(100 \%)$. The severity index was high, indicating the severity of ARF in the elderly ; hence nurses could not leave the bedside during the hemodialysis treatment period in more than $90 \%$ of elderly ARF patients, as these patients required meticulous care. It is concluded that treatment of elderly ARF patients should be conducted with the utmost care in terms of psyco-somatic and surrounding factors.

\section{目的}

急性腎不全に対する血液浄化法は，技術の進歩にも拘 わらず，導入時期の全身状態がより重症化した患者が多 いため, 国内外の成績 ${ }^{11}$ からは, 10 年前と比較して救命率
が上がっているとはいえない. 近年, 高齢化社会の到来 とともに，当院においても血液透析を必要とする高齢急 性腎不全患者が増加している。そこで今回, 高齢者の急 性腎不全の原因，危険因子，予後および透析実施におけ

片岡 亮子 国立病院医療センター人工透析室Ｔ162 新宿区戸山 1-21-1（03-3202-7181） 
る看護上の問題点等につき検討した.

\section{方法}

1986 年から 1990 年までの 5 年間に, 当院にて, 急速な 腎機能低下により乏尿, 温水, 尿毒症, 高K血症を始め とする電解質異常等をきたした状態で，血液透析（持続 的血液濾過法, ECUM を含む) を必要とした 65 歳以上 (平均年齢 76.4 歳, 最高 93 歳) の患者 46 例（男 21 , 女 25）を対象とし，病歴抢よび透析記録から以下の事項に ついて調査した。

1. 臨床像

1）急性腎不全の分類

腎性急性腎不全（腎性）は，脱水等の腎前性誘因によ るものと，糖尿病性腎症や薬剤に起因するものを含めた 腎実質障害によるものに分けて調査した。

2 ）急性腎不全の分類と年齢分布

3 ）急性腎不全の原因（促進因子）

悪性腫喝や神経因性膀胱を原因とする腎後性急性腎不 全（腎後性）を除外し，急性腎不全の原因あるい促進 因子を調査した。また，高血圧・糖尿病・腎孟腎炎・リ ウマチ等で血清クレアチニン $(\mathrm{S}-\mathrm{Cr}) 1.5 \mathrm{mg} / \mathrm{d} l$ 以上ま たはクレアチニンクリアランス (CCr) $50 \mathrm{ml} /$ 分以下の 腎機能低下が認められる既往の有無により，基礎に腎機 能低下のあった群となかった群に分け同様に検討した。

4) 初回血液透析開始時の BUN, S-Cr, dry weight （適正体重）に対する血液透析前の体重比（溢水率とし た).

2. 障害臟器数と予後

腎不全以外の障害臟器数と予後を調査した. 多藏器不 全における障害臟器の判定は平沢ら ${ }^{2)}$ の診断基準に従っ た.すなわち，肝は GOT, GPT $\geqq 100$ ないし総ビりルビ ン $3.0 \mathrm{mg} / \mathrm{d} l$, 心将性心筋梗塞ないし治療を要する不 整脈, 昇圧剤を要する心原性ショック，消化管は輸血を 要する吐・下血, 肺は人工呼吸器を要する, $\mathrm{FiO}_{2} \geqq 0.4 \sim 0.6$ でも $\mathrm{PaO}_{2} \leqq 60$, DIC は $\mathrm{FDP} \geqq 40 \mu \mathrm{g} / \mathrm{m} l$, フィブリノー ゲン $\leqq 200 \mathrm{mg} / \mathrm{d} l$, 血小板 $\leqq 10$ 万, 中枢神経は痛みにのみ 反応するものをそれぞれの臓器不全とした。

3 . 患者の状況

1）血液透析開始時の患者の状況

入室方法と看護体制, 意志柾通の程度, 抑制帯や鎮静 剤の使用の有無を調査した。

\section{2）重症度の評価}

重症度は, 医療処置を点数制で評価する the therapeutic intervention scoring system (TISS) ${ }^{3)}$ で評価した。 TISS は，1点は ECG モニター， 1 時間毎のバイタル サインチェック, 抗生物質静注等 17 項目, 2 点は 2 つの 輸液経路, 気管内チューブまたは気管切開による自発呼
吸等 8 項目, 3 点は 3 つ以上の輸液経路，血管作動物質 の輸注, 抗不整脈剤の持続注入等 21 項目, 4 点は急性腎 不全に対する血液透析，調節呼吸，血小板輸血等 16 項目 からなり,これらの合計点が 13 点以下が中等症, 14〜 43 点は重症, 44 点以上は最重症と分類される.これに基づ き, 対象患者の初回血液透析日 24 時間内に施行された処 置を合計し評価した。

\section{4. 透析方法と透析中の状況}

透析液の種類, 透析方法の工夫, 透析中の血圧低下等 の状況㧍よび対策などにつき調查した。 統計学的処理には, $\mathrm{t}$ 検定を使用した.

\section{結果}

\section{1. 臨床像}

1）急性腎不全の分類（図 1)

46 症例は, 主として脱水等の腎前性誘因による腎性 17 例 $(37 \%)$, 腎実質障害によると考元られる腎性 22 例 (48\%)，腎後性 7 例（15\%）に分類された。

\section{2 ）急性腎不全の分類と年齢分布（図 2 )}

各群に有意差は認められなかったが, 腎後性は他の 2 群と比較すると比較的若年の傾向があった。最高 93 歳の 症例に対する透析は，患者自身扔よび家族の希望により 施行されていた。

3 ）急性腎不全の原因（促進因子）（図 3)

腎後性を除外した 39 症例の急性腎不全の原因(促進因 子）は, 感染症 33\%, 心不全 $21 \%$, 脱水 $21 \%$, 薬剤 $13 \%$, 外傷や手術等のストレス $7 \%$ ，その他 $5 \%$ であった。ま た，高血圧・糖尿病・腎孟腎炎・リウマチ等で S-Cr 1.5 $\mathrm{mg} / \mathrm{d} l$ 以上または $\mathrm{CCr} 50 \mathrm{~m} l /$ 分以下の腎機能低下が認 められる既往の有無により基礎に腎機能低下のあった群 となかった群に分けた時, 基礎に腎機能低下のあった群 の急性腎不全の促進因子は，感染症 35\%，心不全 $23 \%$, 脱水 $15 \%$, 薬剤 $15 \%$ と多かった. 基礎に腎機能低下のな かった群の急性腎不全の原因は, 脱水 31\%, 感染症 23\%, 心不全 23\%，ストレス 15\%の順であった。

4) 初回血液透析開始時の BUN, S-Cr, 溢水率 (図 4) BUN の全症例の平均值は $114 \pm \mathrm{SD} 54 \mathrm{mg} / \mathrm{d} l$ で, 各 群での有意差は認められなかった。S-Cr の全症例の平均 值は $7.6 \pm \mathrm{SD} 3.3 \mathrm{mg} / \mathrm{d} l$ であり, 症例によっては $15 \mathrm{mg} /$ $\mathrm{d} l$ 前後まで上昇していたものも認めた。腎性で怙糖尿病 性腎症が多く, 溢水の治療目的で血液透析が早めに開始 されていたものが多く, 各群に比較して有意に低值で あった．腎後性は，無尿になるまで診断がつかなかった 例も多く, 各群に比較して有意に高値であった。溢水率 は，腎前性誘因による腎性では高度な脱水を認めるもの もあり，いわゆる腎性のものと明らかな差があり，血液 透析中に体重をプラス補正するものが多かった。 


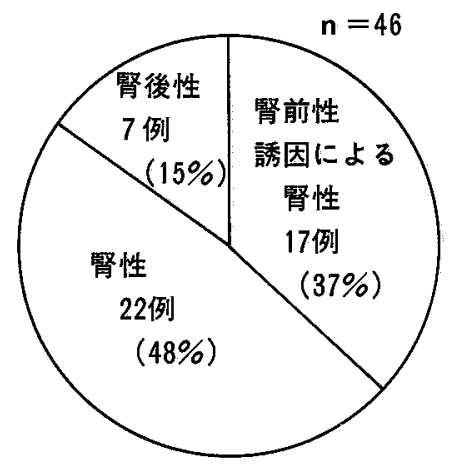

図 1 急性腎不全の分類

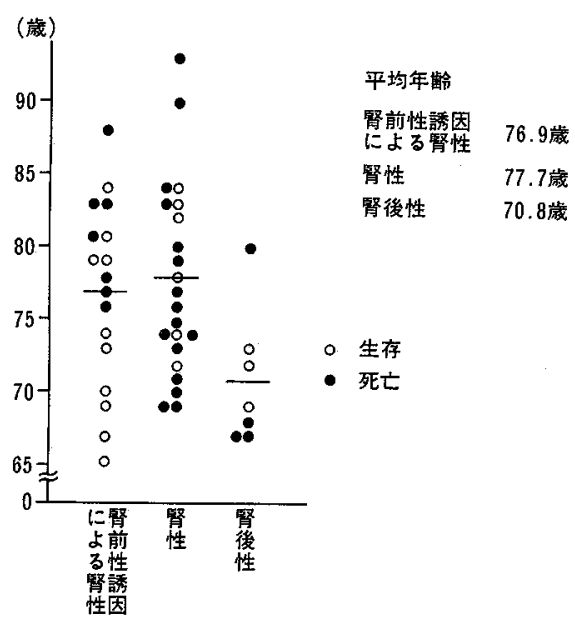

図 2 急性腎不全の分類と年齢分布

\section{2. 障害臟器と予後（図 5 )}

腎不全のみの障害では 12 例中 11 例とほぼ全例生存し ていた。 2 臓器障害例では半数が， 3 臓器以上の障害が あると全例が死亡しており, 救命率は障害臓器数が増す ほど著しく低下していた，全体の転帰は，死し 59\%であ り生存例のうち $89 \%$ は透析より離脱した。

3. 患者の状況

1）血液透析開始時の患者の状況（図 6)

入室方法は $96 \%$ がストレッチャーやベッドのまま，お よび救急車の直接搬入等臥床したままであった。 $88 \%$ の 症例につきっきりの看護を要し，37\%は意志踈通困難が あり, 安全な透析施行のために抑制帯や鎮静剤を必要と していた.

2) TISS による重症度の評価（図 7)

TISS による評価では, 最高は 36 点平均は 23 点で, 重 症が $93 \%$ で中等症以下は $7 \%$ のであった。

4. 透析方法と透析中の状況（図 8)
急性腎不全の原因(促進因子)

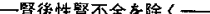

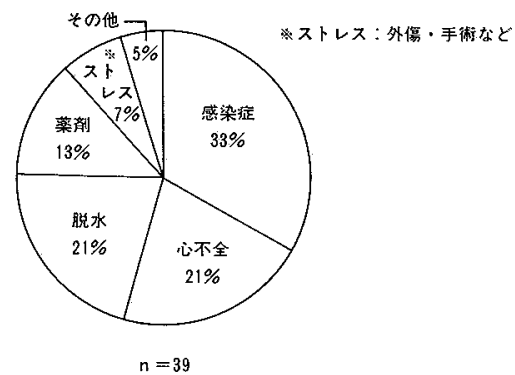

急性腎不全の促進因子

急性腎不全の原因

一基礎に腎機能低下なし一

一一基磷に繁譏能低下あり—
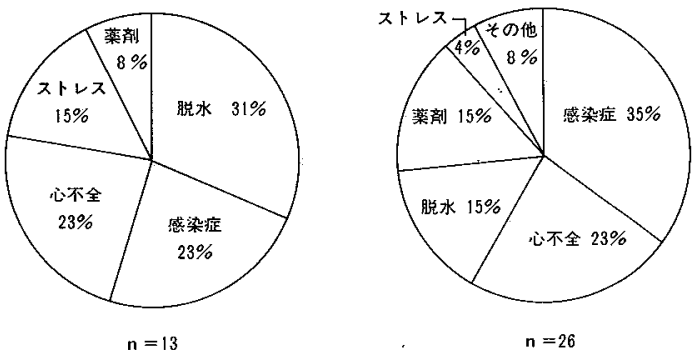

図 3 急性腎不全の原因（促進因子）
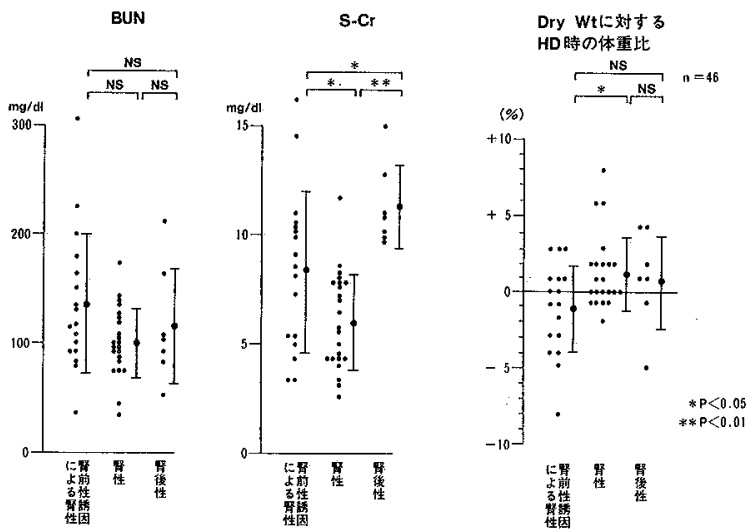

図 4 初回血液透析時の $\mathrm{BUN}$, 血清 $\mathrm{Cr}$, 溢水率

使用した透析液は, 重曹透析液が $80 \%$ であった。酢酸 透析液が $20 \%$ あるは, 当院では 5 年前は主として酢酸 透析が行われていたためである。また，低カリウム血症 によると思われる不整脈が多く見られ，63\%の症例の透 析液のカリウム濃度を若干高め $(3.5 \sim 4.0 \mathrm{mEq} / l)$ に調 節していた. 不均衡症候群や血圧低下の予防のため $49 \%$ にグリセオール®を使用し， ECUM 併用，高 $\mathrm{Na}$ 透析 (透析液 $\mathrm{Na}$ 濃度：148～150 mEq/l)，プライミング時や 透析中にアルブミン製剤の使用等の工夫が行われてい 


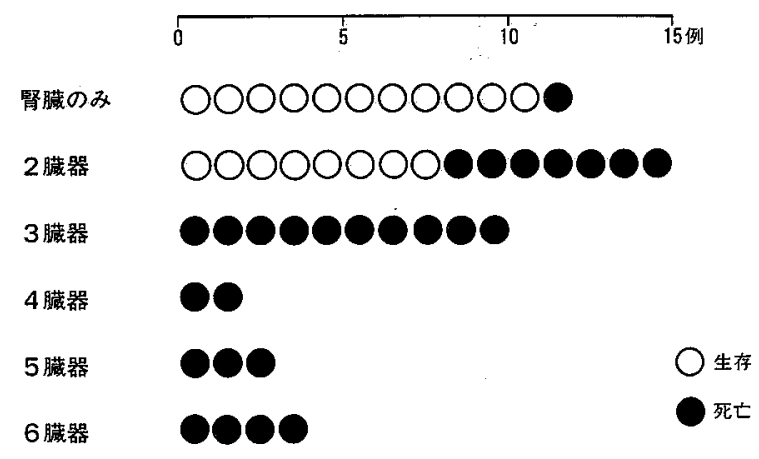

図 5 障害臓器数と予後

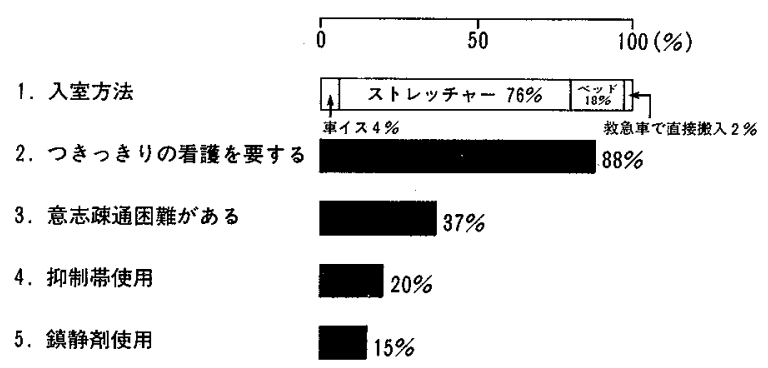

図 6 血液透析開始時の患者の状況

た。収縮期血圧 $90 \mathrm{mmHg}$ 以下の血圧下降は $34 \%$ にみら れ昇圧剤や輸血を必要としていた。抗凝固剂は出血傾向 のある症例には nafamostat mesilate が用いられてい た. 1 回の血液透析中に同時観察を要する輸液経路は 2 箇所以内が $41 \%$ ， 3 箇所以上が $59 \%$ を占めていた. 血流 量は, 循環動態不良のものが多く透析開始 1 時間後で $125 \mathrm{~m} l /$ 分までが $75 \%$ ，終了時にも $60 \%$ と低血流量で施 行されていた.

\section{考案}

高齢者の腎は，加齢による機能低下と予備能の低下か ら他藏器疾患の影響を受けやすい状態にある。また, 水・ $\mathrm{Na}$ ・保持能が低下しているため体液量の減少により，容 易に脱水となり急性腎不全をきたしやすい状態にあると 考えられている4)。我々が調查した急性腎不全の原因お よび促進因子でも，基礎に腎機能低下のないものは脱水 に関連するものが多く,基礎に腎機能低下がある場合は, 急性腎不全の促進因子は感染症，心不全，薬凪が多く認 められ，これまでの報告 ${ }^{4 \sim 6)}$ と同様の結果であった。

急性腎不全に対する血液浄化開始時期について, 最近 では，輸液スペースの確保等を目的として持続的血液濾 過法等も併用し，より早期に開始すべきであるといわれ ている7,8). しかし，この考光方が一般化しているとはい えず，我々の症例でも慢性腎不全の透析導入基準と混同

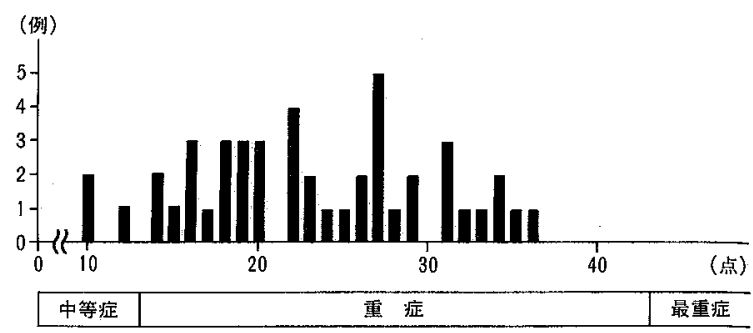

図 7 TISSによる重症度の評価

1. 透析液

2. 透析液 K 調整

3.ダリセオール使用

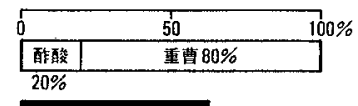

4. ECUM 阱用

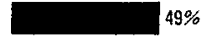

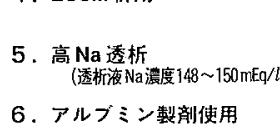

7. 血圧下降 (収縮期血圧 $90 \mathrm{mmHg}>$ )

8. 昇圧剤使用

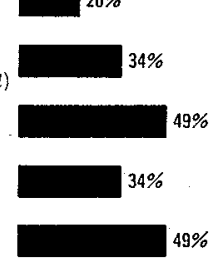

9. 輸血

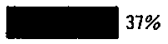

10. 抗凝固剤

11. 同時観察を要する 辅液ライン数

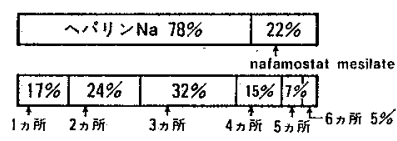

12. 血流 $(\mathrm{ml} /$ 分) HD 開始 1 時間後

終了前

\begin{tabular}{|c|c|c|c|}
\hline 100 & & $100 \sim 125$ & \multirow{2}{*}{$\frac{150}{2 \%}$} \\
\hline $42 \%$ & & $34 \%$ & \\
\hline $22 \%$ & $37 \%$ & & \\
\hline
\end{tabular}

図 8 透析方法と透析中の状況

し，他院扔よび他科でぎりぎりまで保存的治療がなされ， 検査デー夕が極端に悪化して, 極めて重篤な状態に陥つ てから透析室に転送されるという症例が少なくはなく， より早期の血液透析が必要であると考えられた。

また, 急性腎不全は多臟器不全の一分症であることが 多く，その転帰を左右する最重要な因子は合併する他の 臟器不全数であるといわれている 腎以外 2 臟器以上の他藏器障害合併例は全例死亡してお り, 多臟器不全の一分症として急性腎不全の予後が不良 であることを再認識した。しかし，生存例のほとんどは 腎機能が改善しており，高齢であることが急性腎不全の 治療としての透析療法の適応を左右するものではないと 考えた。

初回血液透析開始時の患者の状態は重篤なものが多 
く，96\%は臥床したままの入室で，88\%につきっきりの 看護が必要であった.これは, TISSでも平均 23 点と高度 の医療処置が多い重症者であったことに加光，意志疎通 が困難であり，細心の注意を払って透析を行っても血圧 下降する症例が多く, 観察が最重要であったためである.

これら集中管理を必要とする急性腎不全患者の透析療 法统，我々が日常的に施行している維持透析療法とは全 く異質なものである．しかし，このことを透析療法に直 接携わらない医療関係者は必ずしも十分認識していると はいえず，他科，他院より「急性腎不全が発生したので 透析をして欲しい」という要請で入室してくる場合が多 い。緊急透析となると，主として維持透析目的のために つくられたオープンシステムの透析施設扔よびスタッフ に intensive な透析管理と care を要求することとなる. 言い換えると，高齢急性腎不全患者の看護に重点がおか れると，同時に治療している維持透析患者への看護力が 一時的にしろ減少することになるのである。

平澤ら ${ }^{7,8}$ は, 多臟器不全の一分症としての急性腎不全 の治療では集学的アプローチが必要であり，ICU で治療 すべきであると述べているが, 現状では一部の大学病院 等を除いては，すべての急性腎不全患者をICUで治療す ることや病棟透析を施行することは困難な面もあり，今 後も現在ある施設を活用して透析療法に熟練した透析専 門のスタッフがこれに関わっていくことが多いと思われ る。

三明ら ${ }^{11,12)}$ は，急性腎不全に対応できる医療チ一ムの 体制を整えておくことの必要性を述べている。我々も緊 急時の諸々の局面に応じられるよう，看護婦間，医師， 臨床工学技師とのシステム作りが重要であると考えた。

今後，一般の透析施設で高齢急性腎不全患者の透析を 施行する際考元るべきこととして，他の維持透析患者へ の影響をいかに少なく守るかを十分念頭に祘いた上で， 集中管理される患者の異常の早期発見と, 苦痛の緩和, 不安の軽減に努め, また, 家族への支援と病棟看護婦と の申し送りの充実に努めなければならないと思われた。

\section{結語}

高齢急性腎不全患者の実態を調查し, 看護上の問題点 につき検討した。

1。高齢者の急性腎不全の原因としては，基礎に腎機 能低下のないものでは脱水，手術等が多く，腎機能低下 がある場合はその促進因子としては，感染，心不全，薬 郕等が多く認められた。また，従来からの報告と同じく 急性腎不全の予後は, その他の臟器不全の合併と密接に 関係していた。

2.急性腎不全は，最近では，BUN, S-Cr 等の検查値 にとらわれず, 輸夜スペースの確保や多藏器不全の進展
を予防することも考えて，より早期に血液浄化を開始す べきであると考光られている7,8)ことからすると，当院の 血液透析の開始時期が遅れている症例も少なくなかっ た.

3. 患者の重症度は高く, 多くの患者でさまざまな透 析の工夫と集中度の高い治療・看護を必要としていた。 従来の透析施設で治療する場合には他の維持透析患者に も配慮しつつ，集中管理される患者の身体的，心理的， 環樈的側面を総合的に考えながら，積極的に対応できる 医療チームづくりを日頃から心がけるべきと思われた。

な㧍, 本論文の要旨は第 36 回日本透析療法学会（於神戸） で発表した。

\section{文献}

1）本田西男：急性腎不全一定義, 分類, 臨床統計一. 日本臨床 $49 ： 1217-1220 ， 1991$

2）平沢由平：MOF 診断基準。透析療法マニュアル。 (信楽園病院腎セン夕一編)，92，日本メディカルセ ンター，東京，1989

3) Cullen DJ, Civetta JM, Briggs BA, Ferrara LC : Therapeutic intervention scoring system, a method for quantitative comparison of patient care. Critical Care Medicine 2 : 57-61, 1974

4）本田西男, 菱田 明：高齢者の急性腎不全. 腎と透 析 $26: 667-670,1989$

5）白土 公, 大野丞二：老人科領域。日本臨床 41 : 160-164，1983

6）小田 裕, 新藤光郎, 西 信一, 鉣冶有登, 藤森 貢 : 当施設に扔ける急性腎不全症例の検討. ICU と CCU 14:839-843，1990

7）平澤博之, 志賀英敏, 中西加寿也，上野博一：急性 腎不全と多臟器不全. 腎と透析 $7: 45-50,1991$

8）平澤博之，菅井桂雄，大竹喜雄，織田成人：多臟器 不全と急性腎不全。日本臨床 $49 ： 1406-1410,1991$

9）市田静憲, 青井直樹, 多和田英夫, 渡辺有三：急性 腎不全に対し血液净化を施行した 92 症例について の検討。透析会誌 24：1226-1230，1991

10）小高通夫，小林弘忠，田烟陽一郎，添田耕司，平澤 博之: 多藏器障害 (MOF) 飞抢ける急性腎不全 (ARF). 臨床透析 $2: 1573-1582,1986$

11）三明みち子：急性腎不全の看護。臨床透析 2： 1617-1623，1986

12）三宅代志子，安倉富子，落合陽治：ICUにおける急 性腎不全患者の管理. 看護技術 $29 ： 1021-1026,1983$ 